\title{
Cooperative Learning Structure: Catalyst For Effective Learning For Adult Learners In Higher Education
}

Comfort O. Okpala, North Carolina A \& T State University, USA Amon O. Okpala, Fayetteville State University, USA

\begin{abstract}
In this research study, the impact of cooperative learning structures on adult education student's engagement and learning outcomes were examined. The goals of the study are to (1) examine the impact of participation in cooperative learning structures on student's learning outcomes, (2) examine the impact of participation in cooperative learning structures on student's engagement, and (3) determine student's attitude towards cooperative learning structures. The results from the descriptive and inferential statistics indicate that there were statistically significant differences in the learning outcomes of students that participated in the cooperative learning structures. The results from the qualitative analysis show that students who participated in the cooperative learning environment were actively engaged with peers and teacher.
\end{abstract}

Keywords: Cooperative Learning; Cooperative Teams; Learning Teams; Research Teams

\section{INTRODUCTION}

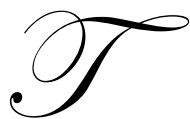

here is a growing concern regarding the quality of students admitted to most graduate programs (Cabrera, Nora, Crissman, Terenzini, Bernal, \& Pascarella, 2002). The author further concluded that most graduate students complete their studies with limited skills and abilities that can be attributed to their graduate preparation. Hart (2002) emphasized that the poor quality of today's graduate students can be attributed to the poor undergraduate preparation. Given these research findings, it is necessary to implement strategies that will improve the quality of learning that occurs at the graduate level. Cooperative learning is a strategy that has been used in K-12 schools and is now being applied in higher education. Literature is replete on the impact of cooperative learning in K-12 arena but, research is limited on the use of cooperative learning in graduate adult education program (Brooks \& Khandker, 2002; Bruffee, 1995; Slavin, 1995). According to Slavin (1995), despite limited research on cooperative learning at the collegiate level, there is evidence of its positive effects on learning at the K-12 setting. Dansereau (1983) concluded in his study of over 300 college students that cooperative learning arrangements were consistently more effective than individual learning strategy for promoting retention of course materials. Frierson (1986) found that black nursing students scored higher on a state based board examination when students were instructed to engage in cooperative learning and studying relative to a comparable group.

Johnson and Johnson (2000) defined cooperative learning as an instructional use of small groups where students work together to maximize their learning. The purpose of this study is to examine the impact of participation in cooperative learning structures on African-American adult education student's learning outcomes and engagement. The following research questions guide the focus of the study:

1. What is the impact of cooperative learning structures on graduate students' learning outcomes?

2. What is the impact of cooperative learning structures graduate students' engagement?

3. What are graduate students' attitudes towards cooperative learning structures? 


\section{THEORETHICAL FRAMEWORK}

The study relied on several core values deemed essential for the development of constructivist and learnercentered instructional environment designed to produce quality graduates (Kuh, Gruce, \& Shoup, 2008). These core values such as the need for instructionally focused classroom leaders that promote quality teaching and learning, the need for classroom leaders with clear articulation of learning objectives with constructive feedback mechanisms, the need for students to actively engage in peer and teacher interactions, and the need for a classroom environment with collaborative relationships among stakeholders. These values are also part of student engagement constructs (Zhao $\&$ Kuh, 2004). Student engagement is an indicator for successful classroom instruction as well as a value outcome for school reform (Chapman, 2003). Cooperative learning is a teaching/learning strategy that strives to create a new type of learning environment. The theoretical framework supporting cooperative learning includes social learning theory, cognitive development theory, and behavioral theory. The social learning theory is grounded in the work of Bandura which begins with the premise that social interaction is essential for human survival. In the learning context, social interdependence refers to students' ability to achieve, adjust psychologically, show social competence, and develop positive relationships. Specifically, positive interdependence, or cooperation, must be structured in the class room (Johnson \& Johnson, 2000).

Cognitive Developmental theory, another theory undergirding cooperative learning, is grounded in the work of Jean Piaget and Lev Vygotsky. Vygotsky presents learning as a societal process and product, while the Piagetian perspective suggests that sociocognitive conflict occurs when individuals work together, and this creates cognitive disequilibrium, that triggers perspective-taking ability and reasoning. Finally, Behavioral Learning theory presupposes that cooperative effort is fueled by intrinsic motivation to earn group rewards (Johnson \& Johnson, 2000).

\section{Essential Elements of Cooperative Learning}

There are five essential elements necessary for successful implementation of cooperative learning (Figure 1) according to Johnson and Johnson (2000). These elements include positive interdependence, individual accountability, face-to-face promotive interaction, small group social skills, and group processing (Johnson, Johnson, \& Smith, 2007). According to the authors, positive interdependence which is from social interdependence theory views cooperation as a positive link for individuals to accomplish a mutual goal through division of labor, roles, and by making sure that each student's grade depends on the performance of the entire group. Individual accountability is essentially the knowledge that not only will the group's product be evaluated, individual contributions will also be measured in determining the final grade for each student. The basic tenet of this element is that while students learn together, they perform alone to ensure that no one rides on the work of others. The need for face to face promotive interaction among members of the group is very important. Although some of the groups' work may be done on an individual basis, most of the tasks are performed through an interactive process where group members provide feedback, challenge one another, teach each other based on their expert knowledge, and encourage their teammates. Students must use appropriate collaborative skills that are positively reinforced by the instructor to allow group members to interact in meaningful and productive way. Both in-class time as well as outside class time should be provided for students to develop and implement trust-building, leadership, decision making, communication, and conflict management skills.

Group processing is basically a metacognitive awareness of the group's goals and progress. It is crucial for the facilitator of a cooperative learning classroom to establish classroom evaluation techniques for the group's functioning process and to use it to maximize members' effectiveness. The group processing evaluation looks at what work, what didn't work, and changes that need to occur (Johnson \& Johnson, 2000). 


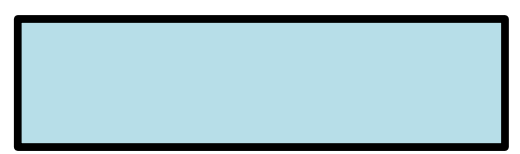

Figure 1: Elements of Cooperative Learning

*Adapted from Johnson \& Johnson, 2000

\section{METHOD}

\section{Participants}

The sampling frame for this concurrent mixed-method research design study consisted of forty-four adult learners enrolled in two graduate research classes in the graduate adult education program at a doctoral granting historically Black college in the southeastern United States. There were twenty-two students in the control group and twenty-two students volunteered to participate on the experimental group. After receiving the Institutional Review Board (IRB) approval to conduct the study, students were asked to sign the approved consent letter to participate in the study. Only those students that voluntarily agreed and signed the consent form were selected for the study. Equal number of students (22) enrolled in the two classes that were used in the study. The majority of the participants were female for both groups (Control, 91.0\%; Experimental, 64.0\%) as illustrated on Table 1. About $81.8 \%$ of the control group members were full-time graduate students while $77.5 \%$ of the experimental group members were full-time graduate students. The majority of the participants on both groups were over thirty years of age and fully employed (See Table 1). 
Table 1: Demographic Characteristics of the Participants

\begin{tabular}{|c|c|c|c|c|}
\hline Variables & Control Count & $\%$ & Exper.Count & $\%$ \\
\hline \multicolumn{5}{|l|}{ Gender } \\
\hline Male & 2 & 9.0 & 8 & 36.4 \\
\hline Female & 20 & 91.0 & 14 & 64.6 \\
\hline \multicolumn{5}{|l|}{ Student Status } \\
\hline Full-time & 18 & 81.8 & 17 & 77.3 \\
\hline Part-time & 4 & 18.2 & 5 & 22.7 \\
\hline \multicolumn{5}{|l|}{ Age } \\
\hline Under 25 & 5 & 22.7 & 7 & 31.8 \\
\hline $25-30$ & 5 & 22.7 & 5 & 22.7 \\
\hline Over 30 years & 12 & 54.6 & 10 & 45.5 \\
\hline \multicolumn{5}{|l|}{ Employment Status } \\
\hline Employed Full-time & 18 & 81.8 & 15 & 68.2 \\
\hline Employed Part-time & 2 & 9.1 & 4 & 18.2 \\
\hline Not Employed & 2 & 9.1 & 3 & 13.6 \\
\hline
\end{tabular}

\section{Research Design}

Johnson and Christensen (2004) emphasized that the use of multiple perspectives strengthens educational research as it adds insights and understanding that might be missed with a single method. In this study, a concurrent mixed -method research design was utilized. Phenomenological qualitative approach was used to examine the experiences of the participants in cooperative learning as well as their engagement with peers and faculty. Controlgroup interrupted time-series quasi experimental design (Creswell, 2009) which was the modification of the singlegroup interrupted time series design was employed as a quantitative method to explore the impact of cooperative learning on the participants' learning outcomes. In this design, two groups of participants that were not randomly assigned were observed for a whole semester with treatment given to the experimental group only. In this design, the participants in the control group were those that utilized the traditional learning strategy while the participants in the experimental group were in the cooperative learning environment. Similar materials were covered by the instructor in both settings but the participants in the cooperative classroom worked in groups inside and outside of the classroom for the entire semester and were strategically monitored by the instructor.

\section{Instrument}

Since this study utilized a concurrent mixed-method research design where data collection and analysis occur at the same time, a mixed-method Cooperative Learning Structure Survey (CLSS) questionnaire was designed by the researchers and was used to collect both quantitative and qualitative data (Creswell, 2009; Patton, 1990). The goal of such methodology was to provide stronger evidence for a conclusion through convergence and corroboration of findings (Creswell, 2009; Johnson \& Christensen, 2004; Johnson \& Onwuegbuzie, 2004; Tashakkori \& Teddlie, 1998). Denzi (1978) identified the use of different types of measure as a good methodological triangulation.

The instrument was designed after a thorough review of literature on cooperative learning and student engagement, and it contained multiple items to increase the reliability and validity in the measure of students' engagement and motivation in cooperative learning structures. The instrument contained four open-ended questions for qualitative data and fourteen closed-ended questions for the quantitative data. The quantitative measures were tested for content reliability at (Cronbach's alpha level of .81) which indicated a strong measure.

The survey questionnaire had three sections. The first section was used to generate demographic information. The second section contained a 14-item, 5-point Likert-type scale, used to assess the perceptions of the participants on group work. The quantitative section was also used to assess the participant's attitude towards their engagement with peers and faculty within and outside of the classroom. The participants were asked to react to 14 statements by selecting one of the five possible choices: $\mathrm{SA}=$ strongly agree, $\mathrm{A}=$ agree, $\mathrm{N}=$ Neutral, $\mathrm{D}=$ disagree, 
$\mathrm{SD}=$ strongly disagree. The third section was used to generate qualitative data through open-ended questions. Four open-ended questions were developed to get the viewpoints of the participants towards group work. Course assessments were used as proxies for learning outcomes as described in the procedure section.

\section{Procedure}

During the first day of class for both classes, students were asked to introduce themselves to the class with information on their academic goals, interest, aspiration, years in the program, experience in the program plus other information that they were willing to share. The students in both classes were not randomly assigned. The students in the experimental class were instructed to form groups of fours/fives with members that shared similar academic goals, interest and aspiration. These groups worked together for the entire semester to accomplish assigned tasks and a research proposal. The students in the control class completed assigned task that also lead to a research project individually. The instructional design for the two classes was similar with similar activities and assignments which minimized any implementation threat to internal validity for differential instructional design (Onwuegbuzie, 2003). Both classes were taught by the same instructor with the same course organization and content which minimized any implementation threat to internal validity from differential selection of instructors. The classes were taught for two hours and fifty minutes once a week in the evening which minimized any implementation threat to internal validity from differential time of day (Onwuegbuzie, 2003). The final grade for the course was calculated as 10 percent for attendance, 10 percent for successful completion of the Institutional Review Board (IRB) training, 20 percent for annotated bibliography of twenty refereed journal articles, 35 percent for research project, and 25 percent for final exam.

\section{ANALYSIS OF DATA}

The researchers divided the data analysis into two phases. First, a qualitative thematic strategy of data analysis was employed to categorize and make judgment about the data. This analytical procedure allowed important themes to emerge. The researchers utilized a prior-research driven approach to identify themes (Boyatzis, 1998). The main themes from the participants' responses were identified and matched with existing categories.

Then quantitative data were analyzed to determine the impact of cooperative learning structures on the participants' engagement and learning outcomes. Descriptive and inferential statistics were used primarily to answer the research questions in the study. To give a more completed description of the responses from the sample, the researchers provided descriptive statistics whenever possible for the participants as a whole as well as separately.

\section{Results}

The participant's responses on the open-ended questions vary. The participants in the experimental classroom value the use of cooperative learning structures in the class. Some of the comments are presented below:

"My group worked so well that my faith in group effectiveness has been reaffirmed"

"The group structure allowed me to learn from four other teachers in my group plus our classroom teacher. It was an amazing experience." 
the control classroom put it "it is hard to get grown folks with different schedules to get things done right, so I hate working in any kind of groups in this program."

Some participants focused on the elements for successful implementation of cooperative learning in an adult education program. The themes that emerged vary from commitment/dedication, group member's quality, team unity/relationship to delegated responsibility. The majority of the participants indicated that commitment/dedication from group members is the most important element for an effective cooperative group. When all the members of a group are highly committed to the success of the group, it can lead to sustainable practices according to Mezirow (2000). This practice according to the author will lead to instrumental learning for the group members. The participants also indicated that leadership in terms of delegated responsibility is another important element of a cooperative group. As one participant stated, "when group members don't take their roles and responsibilities very seriously, then you will have many free riders that depend on others like me because I care about my performance in this program."

The results from the quantitative data presented here is based on the first research questions that focused on the impact of cooperative learning structures of graduate students learning outcomes. To answer this question, a ttest was performed to determine if the learning outcomes of students in the experimental group were significantly different from the learning outcomes of their counterparts in the control group (at the .01 significance level) as measured by a combination of tasks as described in the procedure section.. Then a one-way ANOVA was used to determine if statistically significant differences exist between the mean scores from the two groups. Table 2 provides the descriptive statistics and the one-way ANOVA results. Based on the mean scores, the participants in the experimental group had a higher mean score than their counterparts in the control group. As illustrated in Table 2 , the mean score for the students in the classroom with cooperative structures was 92.4187 , while the students in the classroom without cooperative structures' mean score was 80.4917. The standard deviation for the experimental group was 1.5426, while the SD for the control group was 1.9139. The one-way ANOVA calculation indicates that there is a statistical difference between the mean score of students enrolled in the class with cooperative learning structures and the mean score of students in the traditional classroom.

Table 2: Descriptive Statistics and ANOVA for Learning Outcomes in Graduate Research

Descriptive

\begin{tabular}{|l|c|c|c|c|c|c|}
\hline & N & Mean Score & Std. Dev. & Std. Error & Minimum & Maximum \\
\hline $\begin{array}{l}\text { Experimental } \\
\text { Group }\end{array}$ & 22 & 92.4187 & 8.0472 & 1.5426 & 72.50 & 99.50 \\
\hline $\begin{array}{l}\text { Control } \\
\text { Group }\end{array}$ & 22 & 80.4917 & 9.3764 & 1.9139 & 61.90 & 95.50 \\
\hline All Groups & 44 & 85.5542 & 9.9428 & 1.4328 & 61.90 & 99.50 \\
\hline
\end{tabular}

ANOVA

\begin{tabular}{|l|c|c|c|c|c|}
\hline & $\begin{array}{c}\text { Sum of } \\
\text { Squares. }\end{array}$ & df & Mean Square & F & Sig. \\
\hline Between Groups. & 1134.905 & 1 & 1134.905 & 14.867 & 0.000 \\
\hline Within Groups. & 3511.511 & 42 & 76.337 & & \\
\hline Total. & 4646.416 & 43 & & & \\
\hline
\end{tabular}

\section{DISCUSSION}

This analysis has focused on the impact of the use of cooperative learning structures on the learning outcomes of adult education students in a graduate research class. The findings from the quantitative analysis suggest that there are statistical differences in the learning outcomes of graduate students that participated in classroom with cooperative learning structures as compared to graduate students in the traditional classroom. The 
qualitative findings support the quantitative results that cooperative learning is a strong pedagogical strategy in the improvement of learning outcomes for adult learners in higher education. These findings corroborate with the research conducted by Frierson in 1986 on black nursing students. He concluded that black nursing students that engaged in cooperative learning scored higher on a state based board examination than their counterparts that studied alone. The students in the cooperative classroom formed a learning community within the group that resulted in an increased learning outcome in terms of their individual grade on the final examination as well their final grade for the class. These participants maintained a close relationship and held each other accountable for their success in the class.

It is also important to note that the students in the experimental group were actively engaged with their peers as well as their instructors in and outside of the classroom. The qualitative findings also show that the students in the cooperative learning classroom enjoyed the class more and studied more. Based on the themes that emerged from the qualitative analysis, the adult learners in the experimental group were more dedicated and committed to learning than most of their counterparts in the control group. One unintended result from this study was the overall rating of the instructor as well as the course itself by the participants in this study. The graduate students that participated in the cooperative learning structures overwhelmingly rated the instructor higher than their counterparts in the traditional classroom.

\section{CONCLUSION AND IMPLICATIONS}

Based on the findings and themes that emerged from this study, the researchers can reasonably conclude that the use of cooperative learning structures is an effective teaching and learning strategy for adult learners in graduate program. This conclusion corroborates with Murray (1991) that found that collaborative learning is an important teaching practice that leads to increased learning outcomes. Cranton (2006) and Davidson (1990) found that the use of cooperating learning is an important predictor of positive classroom experiences for ethnically diverse students. It is interesting that the participants from the experimental group in this study indicated positive experiences from the class than their counterparts in the traditional environment. In 1997, Tinto in his review of Student Integration Model placed collaborative learning at the center of academic and social experiences of students in higher education which aligns with the elements of cooperative learning structures.

This research study is one step in the research that should be done to help higher educational leaders and policy makers in their graduate and undergraduate retention and graduation decisions. With the growing interest in fiscal accountability, budgetary cuts, and resource dependency issues for Historically Black Colleges and Universities (HBCUs), it is imperative that researchers continue to conduct studies that are designed to provide relevant information on factors that contribute to the achievement of adult learners in higher education. Both state and local policy makers have found that all aspects of education must be restructured to support student graduation and retention in higher education. It is recommended that further studies with larger sample size be conducted to assess the impact of cooperative learning structures on the learning outcomes of students.

\section{AUTHOR INFORMATION}

Comfort Okpala is a Professor and Interim Chair of Leadership Studies, School of Education at North Carolina A \& T State University. Her teaching interest includes Qualitative Research, Quantitative Research, Higher Education Finance, Leadership Theory, and Community College Leadership. Dr. Comfort Okpala is a noteworthy researcher who has been cited by over three-hundred and eighty times by international and national researchers. Her research agenda is grounded in leadership training and development, social justice, resource equity, and African education and social issues.

Amon Okpala is currently a Professor of Economics at Fayetteville State University, Fayetteville, NC. His research interests involve analyzing Sustainable Development and Economics of Education topics. He has published several articles in the following journals; Journal of Educational Research, Journal of Education for Business, Atlantic Economic Journal, Journal of Applied Business Research, Journal of Developing Society, Journal of Developing Areas, The Review of Black Political Economy, and Journal of Instructional Psychology. 


\section{REFERENCES}

1. Barkeley, E. 2010. Student engagement techniques: A handbook for college faculty. San Francisco, CA: Jossey-Bass.

2. Barkley, E., K. Cross, and C. Major. 2005. Collaborative learning techniques: A handbook for college faculty. San Francisco, CA: Jossey-Bass

3. Boyatzis, R. 1998. Transforming qualitative information: Thematic analysis and code development. Thousand Oaks, CA: Sage Publications

4. Brooks, T., and A. KhandkerA. 2002. A cooperative learning lab: Does the form matter? Contemporary Economic Policy, 20(3): 330-338.

5. Bruffee, K. 199). Collaborative learning: Higher education, interdependence, and the authority of knowledge. Baltimore, MD: Johns Hopkins University Press.

6. Bruffee, K. 199). Sharing our toys: Cooperative learning versus collaborative learning. Change, 27(1): 1218.

7. Chapman, E. 2003. Assessing student engagement rates. ERIC Clearinghouse on Assessment and evaluation: ED482269.

8. Cranton, P. 2006. Understanding and promoting transformative learning: A guide for Educators ( $2^{\text {nd }}$ ed.). San Francisco, CA: Jossey-Bass.

9. Creswell. J. 2009. Research design: qualitative, quantitative and mixed methods approaches ( $2^{\text {nd }}$ ed.). Thousand Oaks, CA: Sage Publications.

10. Dansereau, D. 1983. Manipulating cooperative script to teaching and learning. Journal of Educational Psychology, 79(4), 424-430.

11. Davidson, N. 1990. Cooperative learning in mathematics: A handbook for teachers. Menlo Park, CA: Addison-Wesley.

12. Denzin, N. (1978). The research act: A theoretical introduction to sociological methods. New York: McGraw-Hills

13. Felder, R., G. Felder, and E. Dietz.1998. A longitudinal study of engineering student Performance and retention, V. Comparisons with traditionally-taught students Journal of Engineering Education, 87(4): 469480.

14. Frierson, H. (1986). Two intervention methods: Effects on group of predominantly Black nursing students' board scores. Journal of Research and Development In education, 19(3): 18-23.

15. Hart, L. (2002). Preservice teachers' beliefs and practices after participating in an integrated content/method course. School Science \& Mathematics, 102: 4-14.

16. Johnson, B., \& Christenson, L. (2004). Educational research: Quantitative, qualitative, mixed approaches, $\left(2^{\text {nd }} e d\right.$.). Boston, MA: Pearson Education Inc.

17. Johnson, D., R. Johnson, and K. Smith. 2007. The state of cooperative learning in postsecondary and professional setting. Educational Psychology Review, 19:15-29

18. Johnson, D., and F. Johnson. 200). Joining together: Group theory and group skills ( $4^{\text {th }}$ Ed.). Boston, MA: Allyn \& Bacon.

19. Johnson, B., and A. Onwuegbuzie. 2004. Mixed method research: A research paradigm whose time has come. Educational Researcher, 33(7): 14-26.

20. Kuh, C., T. Cruce, and R. Shoup. 2008. Unmasking the effect of student engagement in first year college grades and persistence. The Journal of Higher Education, 79: 540-563.

21. Mezirow, J. 1994. Understanding transformative theory, Adult Education Quarterly, 44(4): 222-232.

22. Murray, H. 1991. Effective teaching behaviors in the college classroom. In J. C. Smart (Vol. Ed.). Higher Education: Handbook of Theory and Research, Volume 7: 135-172. New York: Agathon Press.

23. Onwuegbuzie, A. 2003. Expanding the framework for internal and external validity in quantitative research. Research in Schools 10(1): 71-90.

24. Pascarella, E., and P. Terenzini. 1991. How college affects student: Findings and insights from twenty years of research. San Francisco, CA: Jossey-Bass.

25. Patton, M. 1990. Qualitative evaluation and research methods. ( $2^{\text {nd }}$ Ed.). Newbury Park, CA: Sage Publications.

26. Slavin, R. 2000. Cooperative learning: Theory, research, and practice. ( $2^{\text {nd }}$ Ed.). Englewood Cliffs, NJ: Prentice-Hall. 
27. Stevenson, H., and J. Stigler. 1992. Learning gap: Why our schools are failing and what we can learn from Japanese and Chinese Education. New York: Touchstone.

28. Tashakkori, A., and C. Teddlie, C. 1998. Mixed methodology: Combining qualitative and quantitative approaches. Thousand Oaks, CA: Sage Publication.

29. Tinto, V. (1997). Classroom as communities: Exploring the educational character of student persistence. Journal of Higher Education, 68(6): 599-623.

30. Tsay, M., and M. Brady. 2010. A case study of cooperative learning and community Pedagogy: Does working in teams make a difference? Journal of Scholarship

31. of Teaching and Learning, 10(2): 78-89.

32. Zhao, C., and G. Kuh. 2004. Adding value: Learning communities and student engagement. Research in Higher Education, 45: 115-136. 
NOTES 